\title{
Residual Antibacterial Activity of Chlorhexidine Digluconate and Camphorated P-monochlorophenol in Calcium Hydroxide-Based Root Canal Dressings
}

\author{
Janir Alves SOARES ${ }^{1}$ \\ Mario Roberto LEONARDO \\ Mário TANOMARU FILHO ${ }^{2}$ \\ Léa Assed Bezerra da SILVA ${ }^{3}$ \\ Izabel Yoko $\mathrm{ITO}^{4}$

\begin{abstract}
${ }^{1}$ Department of Dentistry, Federal University of Vales do Jequitinhonha e Mucuri, Diamantina, MG, Brazil
${ }^{2}$ Departament of Endodontics, School of Dentistry of Araraquara, São Paulo State University, SP, Brazil

${ }^{3}$ Department of Pediatric Clinic, Preventive and Social Dentistry, School of Dentistry of Ribeirão Preto, University of São Paulo, Ribeirão Preto, SP, Brazil

${ }^{4}$ School of Pharmaceutical Sciences of Ribeirão Preto, University of São Paulo, Ribeirão Preto, SP, Brazil
\end{abstract}

\begin{abstract}
The purpose of this study was to evaluate the residual antibacterial activity of several calcium hydroxide $\left[\mathrm{Ca}(\mathrm{OH})_{2}\right]$-based pastes, placed in root canals of dogs' teeth with induced chronic periapical lesions. Root canals were instrumented with the ProFile rotary

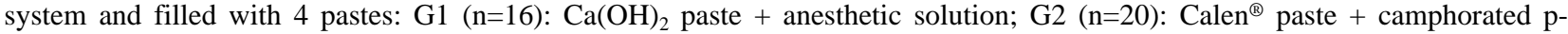
monochlorophenol (CMCP); G3 $(n=18)$ : Calen $^{\circledR}$; and $\mathrm{G} 4(\mathrm{n}=18)$ : $\mathrm{Ca}(\mathrm{OH})_{2}$ paste $+2 \%$ chlorhexidine digluconate. After 21 days, the pastes were removed with size 60 K-files and placed on Petri plates with agar inoculated with Micrococcus luteus ATCC 9341. Pastes that were not placed into root canals served as control. After pre-diffusion, incubation and optimization, the inhibition zones of bacterial growth were measured and analyzed by Mann-Whitney $U$ test at $5 \%$ significance level. All pastes showed residual antibacterial activity. The control samples had larger halos ( $p<0.05)$. The mean residual antibacterial activity halos in G1, G2, G3 and G4 were 7.6; 10.4; 17.7 and $21.4 \mathrm{~mm}$, respectively. The zones of bacterial growth of G4 were significantly larger than those of G1 and $\mathrm{G} 2(\mathrm{p}<0.05)$. In conclusion, regardless of the vehicle and antiseptic, all $\mathrm{Ca}(\mathrm{OH})_{2}$-based pastes showed different degrees of measurable residual antibacterial activity. Furthermore, unlike $\mathrm{CMCP}$, chlorhexidine increased significantly the antibacterial activity of $\mathrm{Ca}(\mathrm{OH})_{2}$.
\end{abstract}

Key Words: apical periodontitis, calcium hydroxide, chlorhexidine, intracanal medicaments, root canal infection.

\section{INTRODUCTION}

Biologically, the formation and persistence of apical abscesses, granulomas and cysts are intimately associated with pulp necrosis secondary to root canal system infection (1). Due to this cause-effect relationship, one of the goals of root canal treatment is to eliminate or significantly reduce the residual necrotic tissue, microorganisms and their byproducts, thus creating favorable conditions for the occurrence of periapical tissue healing (2-4).
Biomechanical preparation is the first and most important step to eliminate an endodontic infection. However, the cutting action of files as well as the flushing and chemical actions of the irrigating solutions are primarily effective against the microbiota situated in the main root canal $(1,5)$. After meticulous cleaning and shaping of the main root canal, the use of calcium hydroxide $\left[\mathrm{Ca}(\mathrm{OH})_{2}\right]$-based pastes as intracanal dressings has been widely recommended for a complementary antiseptic action, among other favorable properties (6-11). However, the antimicrobial activity of these

Correspondence: Prof. Dr. Janir Alves Soares, Universidade Federal dos Vales do Jequitinhonha e Mucuri, Rua da Glória, 187, 39100-000 Diamantina, MG, Brasil. Tel: +55-38-3531-2901. Fax: +55-16-3301-6392. e-mail: janirsoares@citel1.com.br 
pastes is still not fully understood and several questions remain unanswered regarding the time of mantainance of these pastes in the canals, the type of vehicle and the need of adding other anti-septic components to $\mathrm{Ca}(\mathrm{OH})_{2}$.

Clinically, though satisfactory antiseptic results have been obtained with $\mathrm{Ca}(\mathrm{OH})_{2}$-based pastes for up to 7 days (12), studies of hydroxide ion diffusion through dental structure suggest that the minimum time should be 2-3 weeks (9). This is required to reach the threshold alkalinity in order to inactivate or eliminate bacteria and fungi remaining in the root canal system and possibly periapical biofilm microorganisms as well $(1,13)$.

Regarding the vehicles used for preparation of $\mathrm{Ca}(\mathrm{OH})_{2}$-based pastes, aqueous (i.e., distilled water, saline and anesthetic solution) or viscous (i.e., polyethylene glycol and glycerin) hydrosoluble vehicles are the most commonly used. These substances are considered inert from an antiseptic point of view (6).

The presence of strictly anaerobic and facultative gram-positive and gram-negative cocci, bacilli and filaments in the root canal system has been demonstrated $(1,4,5,12)$. These microorganisms show a wide range of susceptibility to calcium hydroxide and therefore the addition of other antimicrobial agents to $\mathrm{Ca}(\mathrm{OH})_{2}$ based pastes has been suggested, such as camphorated p-monochlorophenol (CMCP), which has been shown to be effective against resistant root canal microbiota $(3,5,10,11,14)$. In addition, chlorhexidine digluconate has been used as an alternative vehicle for $\mathrm{Ca}(\mathrm{OH})_{2}$ based pastes because of its broad antimicrobial spectrum, diffusibility and substantivity $(8,11,14,15)$.

Due to the effectiveness of $\mathrm{Ca}(\mathrm{OH})_{2}$-based intracanal medications for treatment of teeth with pulp necrosis and periapical lesions, it is important to determine the duration of their antimicrobial activity and whether it is influenced by paste composition. Thus, this study evaluated the influence of two hydrosoluble vehicles (anesthetic solution and polyethylene glycol) and two antiseptics (CMCP and 2\% chlorhexidine digluconate), on the residual antibacterial activity of $\mathrm{Ca}(\mathrm{OH})_{2}$-based pastes placed in root canals of dogs' teeth with experimentally induced chronic periapical lesions.

\section{MATERIAL AND METHODS}

\section{Induction of Periapical Lesions and Root Canal Therapy}

This study was conducted on 72 root canals of upper and lower premolars of 41 -year-old dogs. The animals were injected intravenously with $3 \%$ sodium nembutal at a dose of $15 \mathrm{mg} / \mathrm{kg}$ body weight, and occlusal cavities were opened, the pulp tissues were carefully removed with Hedstrom files, and root canals were left exposed to the oral environment for 7 days for purpose of contamination. After this period, the access openings were sealed with a 3-mm-thick layer of zinc oxide-eugenol cement (Pulpo Sam; S.S.White, Rio de Janeiro, RJ, Brazil), until the induction of periapical lesions. Standard radiographs were taken at 15-day intervals to monitor the development of radiolucent periapical areas suggestive of chronic periapical lesions, which usually occurred between 60 and 90 days.

The operative procedures were undertaken under rubber dam isolation, followed by antisepsis of the operative field with $5 \%$ iodated alcohol and neutralized with alcohol/ether. After removal of the coronal seal, the septic contents of the initial 2/3 of the root canals were explored and neutralized using $5.25 \%$ sodium hypochlorite as irrigating solution. Subsequently, rotary instrumentation was performed with the ProFile rotary System (Dentsply/Tulsa Dental Products: Tulsa, OK, USA) using size 30 to 60 files with 0.04 and 0.06 tapers according to a crown-down preparation technique. Copious irrigation with $3.6 \mathrm{~mL}$ of $5.25 \%$ sodium hypochlorite was done at each change of file using a syringe and a $27 \mathrm{G}$ needle. Pre-enlargement proceeded with orifice shapers for exploration/neutralization of the apical third of the root canal, maintaining the apical foramen patent with a size $30 \mathrm{~K}$-file, followed by rotary apical preparation. The apical stop was enlarged to a diameter of $0.60 \mathrm{~mm}$ and was located at $1.5 \mathrm{~mm}$ short of the radiographic apex. The smear layer was removed with buffered $14.3 \%$ EDTA solution, which was stirred with a K-file for $5 \mathrm{~min}$. Then, the root canals were flushed with $3.6 \mathrm{~mL}$ of the irrigating solution and dried with paper points. The canals were filled with $\mathrm{Ca}(\mathrm{OH})_{2}-$ based pastes prepared with hydrosoluble vehicles either aqueous (anesthetic solution or $2 \%$ chlorhexidine digluconate solution) or viscous (polyethylene glycol).

Four experimental groups were obtained according to the intracanal medication used: Group 1: $(n=16)$ - $\mathrm{Ca}(\mathrm{OH})_{2}$ p.a. plus anesthetic solution (Citanest 3\% with octapressin - Prilocaine chloryhdrate with felypressin; Astra Chemistry, São Paulo, SP, Brazil); Group 2: $(n=18)$ - Calen ${ }^{\circledR}$ paste (S.S. White Artigos Dentários Ltda, Rio de Janeiro, RJ, Brazil), which is 
composed of $2.5 \mathrm{~g}$ calcium hydroxide, $0.5 \mathrm{~g}$ zinc oxide, 0.05 g colophony and $2 \mathrm{~mL}$ polyethylene glycol 400 as the vehicle; Group 3: $(n=20)$ - Calen ${ }^{\circledR}$ paste associated with camphorated p-monochlorophenol (Calen ${ }^{\circledR} / \mathrm{CMCP}$; S.S. White Artigos Dentários Ltda). This paste is obtained by the addition of $0.15 \mathrm{~mL}$ camphorated pmonochlorophenol to the Calen ${ }^{\circledR}$ paste; Group 4: $(\mathrm{n}=18)-\mathrm{Ca}(\mathrm{OH})_{2}$ p.a. plus $2 \%$ aqueous chlorhexidine digluconate solution (FGM Produtos Odontológicos, Joinville, SC, Brazil).

Calcium hydroxide p.a. (Labsynth Products Ltda, Diadema, SP, Brazil) used in groups 3 and 4 was weighed on an analytical balance and added to the respective vehicles at a ratio of $0.9 \mathrm{~g}$ powder $/ \mathrm{mL}$ solution to obtain a toothpaste consistency. Both pastes were prepared at the time of use. Calen ${ }^{\circledR}$ and Calen ${ }^{\circledR} /$ CMCP pastes were placed into the canals using a syringe with a threaded piston (ML; S.S.White Artigos Dentários Ltda) and a long needle (Gengibrás - 27G; Ibras CBO Ind. Bras., São Paulo, SP, Brazil) with a silicon stop to limit the penetration to the working length. The other two pastes were applied with a \#4 spiral lentulo coupled to a low-speed handpiece. The amount of $\mathrm{Ca}(\mathrm{OH})_{2}$-based paste placed in the root canals was that enough to completely fill the canal space, which was confirmed radiographically.

\section{Evaluation of Residual Antibacterial Activity}

After 21 days, samples of the $\mathrm{Ca}(\mathrm{OH})_{2}$-based

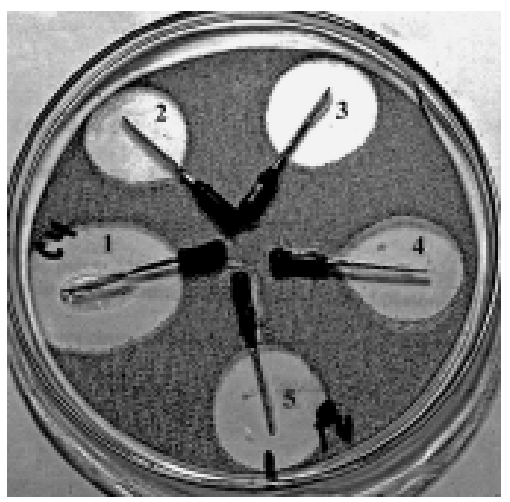

Figure 1. Residual antibacterial activity against Micrococcus luteus ATCC 9341. Starting in C4, in a clockwise direction, the inhibition halos correspond to: 1 - $\mathrm{Ca}(\mathrm{OH})_{2} / 2 \%$ chlorhexidine (control sample); 2 - Calen ${ }^{\circledR} / \mathrm{CMCP} ; 3$ - $\mathrm{Calen}^{\circledR} ; 4$ - $\mathrm{Ca}(\mathrm{OH})_{2} /$ anesthetic; 5 - $\mathrm{Ca}(\mathrm{OH})_{2} / 2 \%$ chlorhexidine. pastes were retrieved from the root canals with size 60 K-files and their residual antibacterial activity was assessed against a Micrococcus luteus ATCC 9341 strain. After cultivation in agar nutrient (An-Nutriente Broth; Difco, Detroit, MI, USA), the test strain was inoculated in Müller Hinton broth (MHb-Müller Hinton broth; Difco) and incubated at $37^{\circ} \mathrm{C}$ for $24 \mathrm{~h}$. Under antiseptic conditions, $1.0 \mathrm{~mL}$ of the Micrococcus luteus ATCC 9341 culture, at a concentration of $10^{6} \mathrm{cfu} / \mathrm{mL}$ and adjusted to 0.5 of the McFarland scale, was added to 20x100 mm Petri plates containing $12 \mathrm{~mL}$ of Müller Hinton agar (Mha-Müller Hinton Medium-Difco). Each plate contained 4 files with different intracanal medicament and 1 file with a freshly prepared past (control sample), disposed radially. After pre-diffusion for $2 \mathrm{~h}$ at $24^{\circ} \mathrm{C}$, the plates were incubated aerobically at $37^{\circ} \mathrm{C}$ for $24 \mathrm{~h}$. To optimize the reading, aliquots of $5 \mathrm{~mL}$ of $0.05 \%$ 2,3,5-triphenyltetrazolium chloride gel -TTC (Sigma, St. Louis, MO, USA) were added which had been prepared with $1.0 \%$ agar (Difco). After solidification, the plates were incubated at $37^{\circ} \mathrm{C}$ for $30 \mathrm{~min}$. The halo of inhibition formed around each file was measured at its largest diameter perpendicular to the file using a millimeter rule under stereomicroscopy. Statistical analysis of the data was performed by Mann-Whitney U test at $5 \%$ significance level.

\section{RESULTS}

Figures 1 and 2 show that the control pastes and

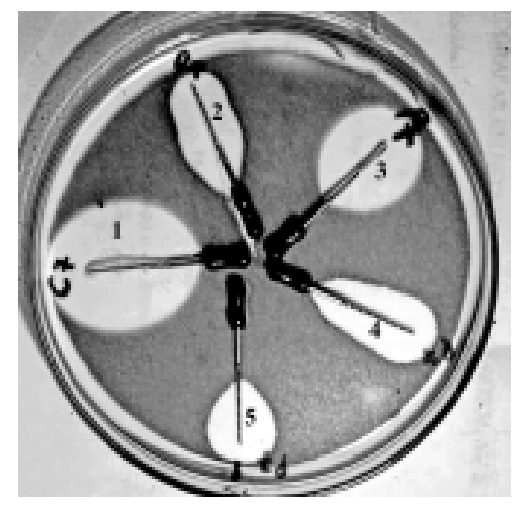

Figure 2. Residual antibacterial activity against Micrococcus luteus ATCC 9341. Starting in C4, in a clockwise direction, the inhibition halos correspond to: 1 - $\mathrm{Ca}(\mathrm{OH})_{2} / 2 \%$ chlorhexidine (control sample); 2 - Calen ${ }^{\circledR} / \mathrm{CMCP} ; 3-\mathrm{Ca}(\mathrm{OH})_{2} / 2 \%$ chlorhexidine; 4 - Calen $^{\circledR} ; 5$ - $\mathrm{Ca}(\mathrm{OH})_{2}$ / anesthetic. 
those retrieved from the root canals exhibited residual antibacterial activity (Tables 1 and 2). In order of increasing residual antibacterial activity the paste can be presented as follows: $\mathrm{Ca}(\mathrm{OH})_{2}$ anesthetic; Calen ${ }^{\circledR /}$

Table 1. Halos of inhibition (in $\mathrm{mm}$ ) of the $\mathrm{Ca}(\mathrm{OH})_{2}$-based pastes that were not applied to root canals (control).

\begin{tabular}{lcccc}
\hline Specimens & $\begin{array}{c}\mathrm{Ca}(\mathrm{OH})_{2}+ \\
\text { anesthetic }\end{array}$ & $\begin{array}{c}\mathrm{Calen}^{\circledR}+ \\
\mathrm{CMPC}\end{array}$ & Calen $^{\circledR}$ & $\begin{array}{c}\mathrm{Ca}(\mathrm{OH})_{2} \\
2 \% \mathrm{CHD}\end{array}$ \\
\hline 1 & 18 & 19 & 15 & 26 \\
2 & 21 & 14 & 20 & 24 \\
3 & 18 & 14 & 16 & 21 \\
4 & 19 & 17 & 18 & 30 \\
5 & 0 & 16 & 20 & 35 \\
6 & - & 20 & 24 & - \\
7 & - & 17 & - & - \\
Means & 15.2 & 16.7 & 18.8 & 27.2 \\
\hline
\end{tabular}

$\mathrm{CMCP}=$ camphorated p-monochlorophenol; $\mathrm{CHD}=$ chlorhexidine .
CMCP, Calen ${ }^{\circledR}$ and $\mathrm{Ca}(\mathrm{OH})_{2} / 2 \%$ chlorhexidine. The means of residual antibacterial activity halos were 7.6; 10.4; 17.7 and $21.4 \mathrm{~mm}$, respectively. Comparatively, Calen ${ }^{\circledR} / \mathrm{CMCP}$ and $\mathrm{Ca}(\mathrm{OH})_{2} /$ anesthetic were equivalent in residual antibacterial activity $(\mathrm{p}>0.05)$. Similar performance was also observed for Calen ${ }^{\circledR}$ and $\mathrm{Ca}(\mathrm{OH})_{2} /$ chlorhexidine digluconate $(\mathrm{p}>0.05)$. In contrast, the halos of inhibition of $\mathrm{Ca}(\mathrm{OH})_{2} / \mathrm{chlorhexidine} \mathrm{digluconate}$ and Calen ${ }^{\circledR}$ were significantly larger that those of Calen ${ }^{\circledR} / \mathrm{CMCP}$ and $\mathrm{Ca}(\mathrm{OH})_{2} /$ anesthetic pastes $(\mathrm{p}<0.01)$. Comparatively, the residual antibacterial activity of Calen ${ }^{\circledR}$ and $\mathrm{Ca}(\mathrm{OH})_{2} /$ chlorhexidine digluconate was similar to the respective controls, while the residual antibacterial activity of Calen ${ }^{\circledR} / \mathrm{CMCP}$ and $\mathrm{Ca}(\mathrm{OH})_{2} /$ anesthetic were significantly lower than that of their controls $(\mathrm{p}<0.05)$. Statistical analysis is presented in detail on Table 3.

\section{DISCUSSION}

After remaining in the root canals for 21 days, all

Table 2. Halos of inhibition (in mm) of residual antibacterial activity $\mathrm{Ca}(\mathrm{OH})_{2}$-based pastes retrieved from the root canals.

\begin{tabular}{lcccc}
\hline Specimens & $\mathrm{Ca}(\mathrm{OH})_{2}+$ anesthetic & Calen $^{\circledR}+\mathrm{CMCP}$ & Calen $^{\circledR}$ & $\mathrm{Ca}(\mathrm{OH})_{2}+2 \% \mathrm{CHD}$ \\
\hline 1 & 11 & 19 & 9 & 22 \\
2 & 8 & 0 & 17 & 21 \\
3 & 0 & 14 & 26 & 15 \\
4 & 7 & 0 & 19 & 14 \\
5 & 12 & 28 & 14 & 20 \\
6 & 13 & 20 & 15 & 14 \\
7 & 3 & 10 & 22 & 14 \\
8 & 4 & 7 & 20 & 30 \\
9 & 6 & 14 & 21 & 22 \\
10 & 13 & 18 & 22 & 30 \\
11 & 13 & 4 & 23 & 30 \\
12 & 12 & 0 & 23 & 35 \\
13 & 10 & 22 & 8 & 21 \\
14 & 9 & 14 & 0 & - \\
15 & 0 & 13 & 13 & - \\
16 & 0 & 5 & 18 & - \\
17 & 0 & 2 & 18 & - \\
18 & - & 7 & 30 & 21.4 \\
19 & - & 2 & - & \\
\hline
\end{tabular}

$\mathrm{CMCP}=$ camphorated p-monochlorophenol; $\mathrm{CHD}=$ chlorhexidine. 
$\mathrm{Ca}(\mathrm{OH})_{2}$-based pastes still showed measurable residual antibacterial activity of different magnitudes. The interpretation of these results must take into account the antibacterial action of calcium hydroxide, the vehicles and antiseptics, as well as the variables related to the methodology used.

The antibacterial action of calcium hydroxide results from its high alkalinity ( $\mathrm{pH} 12-13)$. The hydroxide ions act on molecules or structures that are essential for microbial metabolism or reproduction (9). Furthermore, root canal filling itself is a mechanical barrier to prevent the influx of nutrients and microbial recolonization $(1,2)$. The bactericidal action of CMCP is due to the interaction of chlorine and phenol, its principal ingredients, which inactivate sulphydryl groups (SH) of oxidase and dehydrogenase enzymes and denature the structural proteins, principally the bacterial cellular membrane (3). With respect to chlorhexidine, Jenkins et al. (16) considered that the cationic molecule attaches to the negatively charged bacterial cell wall altering its permeability. Thus, a bacteriostatic effect occurs at low concentrations. At high concentrations, a bactericidal effect is observed by the precipitation or coagulation of citoplasmatic contents. From an antiseptic standpoint, anesthetics and polyethylene glycol are considered inert vehicles (6).

Although no panacea, calcium hydroxide has been proved lethal to microorganisms that compose the endodontic microbiota by direct contact in vitro and in periods that varied from minutes to few days $(3,5,10,11)$. However, in root canals, either in vitro or, especially, in vivo, physicochemical and biological barriers represented by the buffering capacity of dentin and tissue fluid (exudates and blood) reduce the antiseptic efficacy of calcium hydroxide $(11,17)$. As a result, $\mathrm{Ca}(\mathrm{OH})_{2^{-}}$ based dressings should remain for a minimum of 2 to 3 weeks in order to obtain satisfactory alkalinity of root dentin. However, some microorganisms present in the dentinal tubules, such as Enterococcus faecalis, remain resistant to calcium hydroxide $(3,11)$. This justifies the need to add antiseptics such as CMCP or chlorhexidine to $\mathrm{Ca}(\mathrm{OH})_{2}$-based pastes $(11,18)$.

Using the agar diffusion test, it has been shown that the efficacy of an antiseptic is mainly related to its solubility, constant diffusion of the agar medium, toxicity and test organisms used in each experiment $(7,11,18,19)$. Although the methodology used in this study is well known, several factors might have interfered with the results. Concerning the culture medium, the viscosity must be taken into account, volume and

Table 3. Comparison of the means of inhibition halos relative to Tables 1 and 2.

\begin{tabular}{|c|c|c|c|c|c|}
\hline \multirow[t]{2}{*}{ Paired samples } & \multirow{2}{*}{$\begin{array}{c}\text { Differences } \\
\text { between mean }\end{array}$} & \multicolumn{3}{|c|}{ Critical values } & \multirow[t]{2}{*}{ Significance } \\
\hline & & 0.05 & 0.01 & 0.001 & \\
\hline $\mathrm{Ca}(\mathrm{OH})_{2} / \mathrm{CHD} \times \mathrm{Ca}(\mathrm{OH})_{2} / \mathrm{CHD}$-Control & 16.6500 & 20.6438 & 27.3855 & 35.4875 & ns \\
\hline $\mathrm{Ca}(\mathrm{OH})_{2} / \mathrm{CHD} \times$ Calen $^{\circledR}$ & 11.3611 & 13.8442 & 18.3653 & 23.7988 & ns \\
\hline $\mathrm{Ca}(\mathrm{OH})_{2} / \mathrm{CHD}$-Control x Calen ${ }^{\circledR}$ & 23.8167 & 24.3984 & 32.3662 & 41.9418 & ns \\
\hline $\mathrm{Ca}(\mathrm{OH})_{2} / \mathrm{CHD}$-Control x Calen ${ }^{\circledR} / \mathrm{CMCP}$ & 33.4714 & 23.5930 & 31.2977 & 40.5572 & $1 \%$ \\
\hline $\mathrm{Ca}(\mathrm{OH})_{2} / \mathrm{CHD}$-Control x Ca(OH)$)_{2} /$ ANS & 34.9000 & 25.4833 & 33.8054 & 43.8068 & $1 \%$ \\
\hline Calen $^{\circledR}$ x Calen ${ }^{\circledR}$-Control & 4.1944 & 18.9941 & 25.1970 & 32.6516 & ns \\
\hline Calen ${ }^{\circledR} \times \mathrm{Ca}(\mathrm{OH})_{2} /$ ANS-Control & 11.0833 & 24.3984 & 32.3662 & 41.9418 & ns \\
\hline Calen $^{\circledR}$-Control x Calen ${ }^{\circledR} / \mathrm{CMCP}$ & 9.6548 & 22.4168 & 29.7374 & 38.5353 & ns \\
\hline Calen ${ }^{\circledR}$ x Calen ${ }^{\circledR} /$ CMCP & 24.1139 & 13.0908 & 17.3659 & 22.5036 & $0.1 \%$ \\
\hline Calen ${ }^{\circledR} \mathrm{x} \mathrm{Ca}(\mathrm{OH})_{2} /$ ANS & 36.1701 & 13.8442 & 18.3653 & 23.7988 & $0.1 \%$ \\
\hline Calen $^{\circledR} / \mathrm{CMCP} \times \mathrm{Ca}(\mathrm{OH})_{2} /$ ANS & 12.0562 & 13.5146 & 17.9280 & 23.2321 & ns \\
\hline Calen $^{\circledR} / \mathrm{CMCP}$ x Ca(OH) $)_{2} /$ ANS-Control & 1.4286 & 23.5930 & 31.2977 & 40.5572 & ns \\
\hline Calen $^{\circledR} / \mathrm{CMCP} \times \mathrm{Ca}(\mathrm{OH})_{2} / \mathrm{CHD}$ & 35.4750 & 13.5146 & 17.9280 & 23.2321 & $0.1 \%$ \\
\hline Calen ${ }^{\circledR} /$ CMCP x Calen ${ }^{\circledR} /$ CMCP-Control & 18.6536 & 17.6947 & 23.4733 & 30.4179 & $5 \%$ \\
\hline $\mathrm{Ca}(\mathrm{OH})_{2} / \mathrm{ANS} \times \mathrm{Ca}(\mathrm{OH})_{2} / \mathrm{CHD}$ & 47.5313 & 14.2456 & 18.8978 & 24.4887 & $0.1 \%$ \\
\hline $\mathrm{Ca}(\mathrm{OH})_{2} / \mathrm{ANS} \times \mathrm{Ca}(\mathrm{OH})_{2} /$ ANS-Control & 29.2813 & 20.6438 & 27.3855 & 35.4875 & $1 \%$ \\
\hline
\end{tabular}

$\mathrm{CHD}=2 \%$ chlorhexidine digluconate $\mathrm{CMCP}=$ camphorated $\mathrm{p}$-monochlorophenol; $\mathrm{ANS}=$ anesthetic solution; $\mathrm{ns}=$ nonsignificant . 
depth of agar medium, the $\mathrm{pH}$ of the substrates in the plates, the load and concentration of ions in the medium, the conditions of storage of the agar plates, the contact of the experimental material with the agar, the time, the temperature of incubation of the plates and the optimization of the reading. The variables related to the antiseptic refers to weight, molecular size and form, sensitivity of the medication, as well as its solubility and diffusion in the water-based agar medium. Regarding the test microorganism, its origin (wild strains or collection species), the density of the inoculum and the type of organism should be ascertained. The time and the point or area for reading the halos of inhibition must also be defined. The lack of standardization is possibly the main cause of variations in results when this methodology is used $(3,7,10,19,20)$. The present study used as an indicator of residual antimicrobial activity, the standard strain Micrococcus luteus ATCC 9341, which is a strictly aerobic gram-positive coccus commonly found in root canals and easily cultured in vitro.

In this study, the viscosity, volume, depth of the agar medium, conditions of storage of the agar plates, contact of the experimental material with the agar, density of the inoculum, as well as the time and temperature of incubation of the plates and the location to read the halos of inhibition were standardized. Moreover, after placement of the intracanal medications, there was a 2-h pre-diffusion period at room temperature, which, according to Leonardo et al. (19), corresponde to the long-term diffusion of the dressing through the root dentine. In addition, after 24-h incubation, TTC gel was applied to optimize the reading. The red compound formed by redox reaction of viable or growing microorganisms facilitates the reading of diffusion and inhibition halos $(19,20)$. Thus, it was shown that in 1 sample of Calen ${ }^{\circledR}$ group and in 3 samples of Calen ${ }^{\circledR} / \mathrm{CMCP}$ and $\mathrm{Ca}(\mathrm{OH})_{2} /$ anesthetic pastes the diffusion occurred without the formation of inhibition halos.

As with the example of distilled water and glycerin, the anesthetic solution behaved as an inert vehicle, without antibacterial activity, and therefore the antibacterial effect observed by this paste must be due to calcium hydroxide effect. The viability of evaluating the antimicrobial activity of $\mathrm{Ca}(\mathrm{OH})_{2}$ in an agar medium has been questioned because the bactericidal activity of $\mathrm{Ca}(\mathrm{OH})_{2}$ is associated with its alkalinity, which would be affected by the buffering capacity of the culture medium associated with its low solubility. Compara- tively, in the root canal system, dentin also exerts a neutralizing action on hydroxyl ions (17), which are progressively replaced by the continuous diffusion of $\mathrm{Ca}(\mathrm{OH})_{2}$. Therefore, a period of pre-diffusion must occur before evaluation to verify the antiseptic action of calcium hydroxide in agar, otherwise it will be evaluated as inefficient $(3,7)$.

The anesthetic solution has been used as a vehicle for calcium hydroxide in many clinical situations involving periapical pathology (6). After remaining in the root canals for 21 days, the $\mathrm{Ca}(\mathrm{OH})_{2}$ /anesthetic solution paste showed a significant reduction in its antibacterial activity, compared to Calen ${ }^{\circledR}, \mathrm{Ca}(\mathrm{OH})_{2} /$ chlorhexidine and its respective controls. This behavior may be partially attributed to the $\mathrm{pH}$ of the vehicle, which is acid (pH4.5) and perhaps to its greater solubility in the tissue fluids. From an antiseptic point of view, this type of paste must be renewed after approximately 21 days, if a longer treatment is needed.

There have been positive reports of $\mathrm{Ca}(\mathrm{OH})_{2} /$ CMCP paste $(3,7,10,19)$. However, a negative synergism seemed to have occurred in this study because the residual action of the $\mathrm{Ca}(\mathrm{OH})_{2} / \mathrm{CMCP}$ paste was significantly less than that of the formulation without CMCP, and the control samples showed similar results. The progressive loss of CMCP from the root canal is known, but surprisingly, CMCP seemed to reduce the bactericidal activity of calcium hydroxide.

The Calen ${ }^{\circledR}$ paste maintained a stable antiseptic action or, in other words, its residual antibacterial activity was similar to that of the control samples. Leonardo et al. (19) observed similar results against Micrococcus luteus and Enterococcus faecalis. In contrast, Gomes et al. (7) noted the smallest zones of inhibition of bacterial growth for Calen ${ }^{\circledR}$ paste. Possibly, their results are due to the readings being based on the lowest values of inhibition halos and, above all, for not undertaking an optimization stage before reading. A relevant factor related to the methodology used in the present study was the optimization of the culture medium with TTC gel. This procedure, according to Begue and Kline (20) helps distinguishing the halo of inhibition of bacterial growth that frequently is interpreted as a halo of diffusion of material.

The fact that the largest halos of inhibition were observed for the $\mathrm{Ca}(\mathrm{OH})_{2} /$ chlorhexidine paste may be attributed to the positive synergism between these two antiseptics, as well as to the greater solubility and 
diffusion of chlorhexidine in the agar medium. Siren et al. (18) reported that chlorhexidine increases the antiseptic action of calcium hydroxide. Chlorhexidine digluconate in a liquid or gel form has been used as an irrigating solution or intracanal medication, in vitro, in situ and in vivo, in concentrations that range from 0.2 to $5 \%(8,14-16)$. Its marked antimicrobial substantivity as an intracanal medication must also be emphasized $(15,18)$. Comparatively, in the antisepsis of dentinal tubules infected with Enterococcus faecalis, CMCP has shown greater efficacy than $\mathrm{Ca}(\mathrm{OH})_{2}(11)$, while chlorhexidine in the form of a sustained-release device or solution showed a performance similar to that of CMCP (14) and superior to that of $\mathrm{Ca}(\mathrm{OH})_{2}(8,18)$.

All control materials showed larger halos of inhibition in relation to the samples retrieved from root canals, especially $\mathrm{Ca}(\mathrm{OH})_{2}$ /anesthetic and Calen ${ }^{\circledR} / \mathrm{CMCP}$. Although the precise amount of each long-term dressing used in the diffusion test was not determined, the results suggest that the components of long-term dressings originating from the root canals showed a progressive reduction in their antiseptic capacity, possibly by being consumed in physicochemical and biological processes, for example: 1) calcium hydroxide carbonation; 2) organic material dissolution; 3) reaction with bacterial organic components (proteins and phospholipids); 4) neutralization by dentine buffering system. Additionally, an important fraction of calcium hydroxide is dissolved by tissue fluids, via the apical foramen.

It should be emphasized that the $\mathrm{Ca}(\mathrm{OH})_{2} /$ chlorhexidine paste showed a notable residual antiseptic activity, whose halos of inhibition were larger than those of the control materials. This behavior may be attributed to the greater diffusibility of chlorhexidine in agar, as well as its concentration. Due to its broad antiseptic spectrum, antibacterial substantivity, low surface tension, dentin diffusibility and relative low cytotoxicity, 2\% chlorhexidine has been shown to be a promising vehicle for calcium hydroxide intracanal medication for endodontic treatment and re-treatment of teeth with pulp necrosis associated with periapical lesions $(15,16,18)$.

Although the agar diffusion test has some limitations, according to the methodology proposed and based on the results of this study, it may be conclude that all $\mathrm{Ca}(\mathrm{OH})_{2}$-based pastes showed measurable residual antibacterial activity against the standard strain Micrococcus luteus ATCC 9341 after 21 days in the root

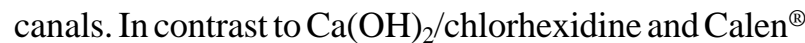
pastes, Calen ${ }^{\circledR} / \mathrm{CMCP}$ and $\mathrm{Ca}(\mathrm{OH})_{2} /$ anesthetic pastes showed a significant reduction in their residual antibacterial activity. Furthermore, unlike camphorated monochlorophenol, $2 \%$ chlorhexidine digluconate increased significantly the antibacterial activity of $\mathrm{Ca}(\mathrm{OH})_{2}$.

\section{RESUMO}

Este estudo objetivou mensurar a atividade anti-bacteriana residual de várias pastas à base de hidróxido de cálcio $\left[\mathrm{Ca}(\mathrm{OH})_{2}\right]$, após permanecerem em canais radiculares de cães com lesões periapicais crônicas induzidas. Os canais radiculares foram instrumentados com o sistema Profile e preenchidos com quatro diferentes pastas: $\mathrm{G} 1-\mathrm{Ca}(\mathrm{OH})_{2}$ p.a./solução anestésica $(\mathrm{n}=16)$, G2-Calen ${ }^{\circledR} /$ PMCC $(n=20)$, G3-Calen ${ }^{\circledR}(n=18)$ e G4-Ca(OH) 2 p.a./solução de digluconato de clorexidina a $2 \%(n=18)$. Transcorridos 21 dias, amostras foram recuperadas dos canais radiculares com limas Kerr \#60 e colocadas em placas de Petri com ágar semeado com Micrococcus luteus ATCC 9341. Pastas não aplicadas nos canais radiculares serviram como controle. Após pré-difusão, incubação e otimização, as zonas de inibição do crescimento bacteriano foram mensuradas e analisadas pelo teste de Mann-Whitney $(a<0.05)$. Verificou-se que todas as pastas apresentaram ação antibacteriana residual, com maiores halos para as amostrascontroles. As médias dos halos de inibição para G1, G2, G3 e G4 foram 7,6; 10,4; 17,7 e 21,4 mm, respectivamente. Os halos de inibição de G4 foram significativamente superiores as de G1 e G2 $(\mathrm{p}<0.05)$. Portanto, independentemente do veículo, todas as pastas à base de $\mathrm{Ca}(\mathrm{OH})_{2}$ determinaram, em diferentes magnitudes, atividade anti-bacteriana residual mensurável. Ademais, diferentemente do PMCC, a solução de digluconato de clorexidina a $2 \%$ ampliou significativamente, a atividade anti-bacteriana residual do hidróxido de cálcio.

\section{REFERENCES}

1. Soares JA, Leonardo MR, Tanomaru Filho M, Silva LAB, Ito IY. Effect of biomechanical preparation and calcium hydroxide pastes on the anti-sepsis of root canal systems in dogs. J Appl Oral Science 2005;12:110-117.

2. Soares JA, Leonardo MR, Silva LAB, Tanomaru Filho M, Ito IY. Histomicrobiologic aspects of the root canal system and periapical lesions in dogs' teeth after rotary instrumentation and intracanal dressing with $\mathrm{Ca}(\mathrm{OH})_{2}$ pastes. J Appl Oral Sci 2006;14:355-364.

3. Siqueira Jr JF, Uzeda M. Influence of different vehicles on the antibacterial effects of calcium hydroxide. J Endod 1998;24:663-665.

4. Sjögren U, Fidgor D, Persson S, Sundqvist G. Influence of infection at the time of root filling on the outcome of endodontic treatment of teeth with apical periodontitis. Int Endod J 1997;30:297-306.

5. Orstavik D, Haapasalo M. Disinfection by endodontic irrigants and dressings of experimentally infected dentinal tubules. Endod Dent Traumatol 1990;6:142-149.

6. Fava LRG, Saunders WP. Calcium hydroxide pastes: classifi- 
cation and clinical indications. Int Endod J 1999;32:257-282.

7. Gomes BPFA, Ferraz CCR, Garrido FD, Rosalen PL, Zaia AA, Teixeira FB, Souza-Filho FJ. Microbial susceptibility to calcium hydroxide pastes and their vehicles. J Endod 2002;28:758-761.

8. Heling I, Steinberg D, Kenig S, Gavrilovich I, Sela MN. Efficacy of a sustained-release device containing chlorhexidine and $\mathrm{Ca}(\mathrm{OH})_{2}$ in preventing secondary infection of dentinal tubules. Int Endod J 1992;25:20-24.

9. Siqueira Jr JF, Lopes HP. Mechanisms of antimicrobial activity of calcium hydroxide: a critical review. Int Endod J 1999;32:361-369.

10. Siqueira Jr JF, Uzeda M. Disinfection by calcium hydroxide pastes of dentinal tubules infected with two obligate and one facultative anaerobic bacteria. J Endod 1996;22:674-676.

11. Portenier I, Waltino T, Orstavik D, Haapasalo M. The susceptibility of starved, stationary phase, and growing cells of Enterococcus faecalis to endodontic medicaments. J Endod 2005;31:380-386.

12. Sjögren U, Fidgor D, Spangberg L, Sundqvist G. The antimicrobial effect of calcium hydroxide as a short-term intracanal dressing. Int Endod J 1991;24:119-125.

13. Leonardo MR, Silva LAB, Rossi MA, Ito IY, Bonifácio KC. Evaluation biofilm and microorganisms on the external root surface in human teeth. J Endod 2002;28:815-818.
14. Heling I, Sommer M, Steinberg D, Friedman M, Sela MN. Microbiological evaluation of the efficacy of chlorhexidine in a sustained-release device for dentine sterilization. Int Endod J 1992;25:15-19.

15. Komorowski R, Grad H, Wu XY, Friedman S. Antimicrobial substantivity of chlorhexidine-treated bovine root dentin. J Endod 2000;26:315-317.

16. Jenkins S, Addy M, Wade $\mathrm{W}$. The mechanism of action of chlorhexidine - A study of plaque growth on enamel inserts in vivo. J Clin Periodontol 2002;15:415-424.

17. Portenier I, Haapasalo H, Rye A, Waltino T, Orstavik D, Haapasalo M. Inactivation of root canal medicaments by dentine, hydroxyapatite and bovine serum albumin. Int Endod J 2001;34:184-188.

18. Siren EK, Haapasalo MP, Waltino TM, Orstavik D. In vitro antibacterial effect of calcium hydroxide combined with chlorhexidine or iodine potassium iodide on Enterococcus faecalis. Eur J Oral Sci 2004;112:326-331.

19. Leonardo MR, Silva LAB, Tanomaru Filho M, Bonifácio KC, Ito IY. In vitro evaluation of antimicrobial activity of sealers and pastes used in Endodontics. J Endod 2000;26:391-394.

20. Begue WJ, Kline RM. The use of tetrazolium salts in bioautographiprocedures. J Chromatogr 1972;64:182-184.

Accepted October 26, 2006 